\title{
Vitamin D receptor gene polymorphisms in type 1 diabetes mellitus: a new pattern from Khorasan province, Islamic Republic of Iran
}

\author{
S. Bonakdaran, ${ }^{7}$ M.R. Abbaszadegan, ${ }^{2}$ E. Dadkhah ${ }^{2}$ and M. Khajeh-Dalouie ${ }^{3}$
}

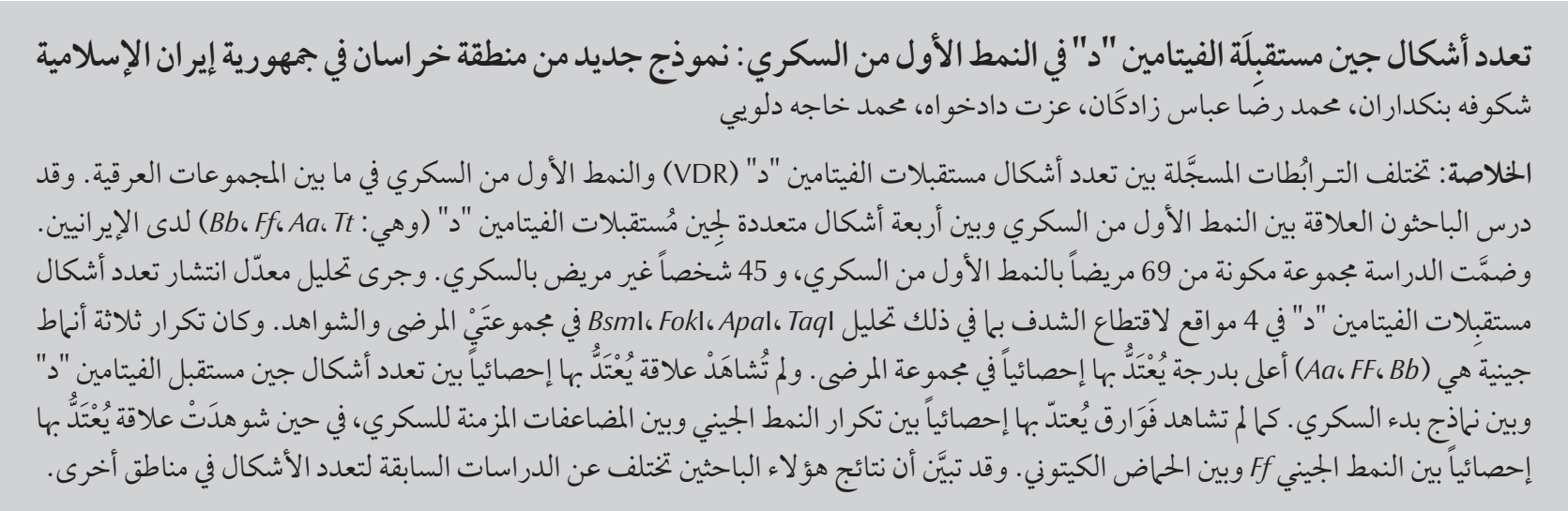

ABSTRACT Reported associations between vitamin D receptor (VDR) polymorphism and type 1 diabetes mellitus vary across ethnic groups. We studied the association between type 1 diabetes and 4 VDR gene polymorphisms $(B b, F f, A a$ and $T t)$ in an Iranian population. A group of 69 patients with type 1 diabetes mellitus and 45 unrelated healthy subjects were recruited. The prevalence of VDR polymorphisms in 4 restriction fragment length polymorphism sites including Bsml, Fokl, Apal and Taql were analysed in patients and controls. The frequencies of 3 genotypes $(A a, F F$ and $B b$ ) were significantly higher in the patient group. The relationship between VDR gene polymorphisms and onset pattern of diabetes was not significant. There were no significant difference between the genotype frequencies and chronic complications of diabetes, but the relationship between the $F f$ genotype and ketoacidosis was significant. Our results differ from previous polymorphism studies in other regions.

Polymorphismes du gène du récepteur de la vitamine $D$ et diabète de type 1 : un nouveau modèle dans la province de Khorasan (République islamique d'Iran)

RÉSUMÉ Les associations observées entre le polymorphisme du récepteur de la vitamine $\mathrm{D}$ et le diabète de type 1 varie en fonction des groupes ethniques. Nous avons étudié l'association entre le diabète de type 1 et quatre polymorphismes du gène du récepteur de la vitamine $\mathrm{D}$ (génotypes $B b, F f, A a$ et $T t$ ) dans une population iranienne. Un groupe de 69 patients atteints de diabète de type 1 et 45 témoins en bonne santé sans lien entre eux ont été recrutés pour cette étude. La prévalence des polymorphismes de ce gène sur quatre sites de polymorphisme de la longueur des fragments de restriction (notamment Bsml, Fokl, Apal et Taql) a été analysée dans les deux groupes. La fréquence de trois génotypes $(A a, F F$ et $B b)$ était nettement supérieure dans le groupe des patients. Le lien entre les polymorphismes géniques du récepteur de la vitamine D et l'apparition d'un diabète n'était pas significatif. Aucune différence importante n'a été observée entre la fréquence des génotypes et les complications chroniques du diabète. Toutefois, le lien entre le génotype $F f$ et l'acidocétose était fort. Nos résultats diffèrent des études antérieures sur le polymorphisme dans d'autres régions. 


\section{Introduction}

Type 1 diabetes mellitus (DM) is a common autoimmune endocrinopathy that results from an interaction of environmental and genetic factors. This interaction is believed to lead to immune destruction of insulin-producing beta cells by T-cell infiltration of the pancreatic islets [1]. In addition to its calciotropic effect, vitamin D has potent non-calcaemic effects and is involved in the modulation and regulation of immune systems [2-6]. Vitamin $\mathrm{D}$ deficiency has been shown to accelerate the onset of type $1 \mathrm{DM}$ [7]. Moreover, vitamin D deficiency leads to impaired insulin secretion, which is reversible by 1,25-dihydroxyvitamin $\mathrm{D}$ administration [8]. Other studies suggest that the active metabolite of vitamin $\mathrm{D}$ decreases the incidence and development of autoimmune diseases such as type $1 \mathrm{DM}$ and also acts as an immunosuppressant agent $[9,10]$. The biological effect of vitamin $\mathrm{D}$ is thought to occur by binding to the vitamin $\mathrm{D}$ receptor (VDR) which belongs to the steroid receptor superfamily and is widely expressed in many cell types including lymphocytes (activated $\mathrm{T}$ lymphocytes, B cells), antigen-presenting cells (including monocytes, macrophages, dendritic cells) and pancreatic islet cells [11-13].

Although many polymorphisms exist in the VDR gene, their effect on VDR protein function and signalling is unknown [14]. Based on the effect of the VDR ligand on immune function, an association between type $1 \mathrm{DM}$ and VDR polymorphisms is likely. The effect of VDR polymorphisms on insulin secretion has been reported before [15]. Four major polymorphic sites have been described within the VDR gene. A polymorphic FokI site in exon-2 results in an alternative transcription initiation site, leading to a protein variant with 3 additional amino acids at the amino terminus [4]. Polymorphic BsmI and Apal sites are present in intron- 8 , and a silent $\mathrm{T}$ to $\mathrm{C}$ substitution creates a Taq $\mathrm{I}$ polymorphic site in exon-9 [16].

An association between VDR polymorphism and type $1 \mathrm{DM}$ has been reported in some studies; however, it appears to vary across ethnic groups [17-23]. The aim of this study was to investigate the relationship of VDR gene polymorphism to the risk of type $1 \mathrm{DM}$ and its association with the onset pattern of diabetes (acute or slow onset) in an Iranian population in Khorasan province.

\section{Methods}

\section{Sample collection}

The study was carried out in Mashhad, Islamic Republic of Iran, during 2006-07. Patients were drawn from the Parsian diabetes clinic, which is a referral centre for diabetic patients and cares for more than 500 patients with type $1 \mathrm{DM}$. Blood samples were obtained from 69 Iranian type 1 DM patients (41 females $/ 28$ males) diagnosed with type $1 \mathrm{DM}$ according to World Health Organization criteria (pancreatic beta-cell destruction as the primary cause of diabetes, and tendency to ketoacidosis), under age 35 years and C-peptide-negative. Another group of 45 unrelated healthy volunteers (26 females/19 males) with a socioeconomic status similar to that of the patients, were also recruited from classmates or friends of the patients.

Demographic and basic clinical variables were collected such as age, sex, time of onset of diabetes, time of starting insulin treatment and history of ketoacidosis and complications such as hypertension, retinopathy, nephropathy, dyslipidaemia, concomitant autoimmune disorders. The patients were divided into 2 groups: acute onset $(<6$ months from onset of diabetes to start of insulin treatment); and slow onset (> 12 months from diabetes onset to insulin treatment).
All patients gave informed voluntary consent to participate in the study according to the protocol approved by the local ethics committee of Mashhad University of Medical Sciences and in accordance with the ethical standards of the Helsinki Declaration.

\section{DNA isolation and PCR experiments}

Blood samples were collected in EDTA tubes and genomic DNA was extracted using the salting out method. The BsmI, FokI, ApaI and TaqI polymorphic sites were considered. Polymerase chain reaction (PCR) amplification was performed using 3 sets of primers - VDR1 (for BsmI), VDR2 (for FokI), and VDR3 (for both ApaI and TaqI) - as described previously $[17,22]$, using the Techgene thermocycler (Techne). After initial denaturation for $5 \mathrm{~min}$. at $95^{\circ} \mathrm{C}$, samples were subjected to 30 cycles of amplification, $25 \mathrm{~s}$ at $94^{\circ} \mathrm{C}, 20 \mathrm{~s}$ at the relevant primer pair annealing temperature (Table 1 ) and $20 \mathrm{~s}$ at $72{ }^{\circ} \mathrm{C}$. The final step was a $5 \mathrm{~min}$. hold at $72^{\circ} \mathrm{C}$. Amplified DNA was digested overnight with suitable amounts of reference restriction enzymes (Fermentas) in the restriction protocol at $37^{\circ} \mathrm{C}$ or $4 \mathrm{~h}$ at $55^{\circ} \mathrm{C}$ according to the manufacturer's instructions (Table 1). Digestion products were electrophoresed on 3\% agarose gel containing $0.4 \mathrm{mg} /$ L ethidium bromide. The polymorphism was documented by photographing under UV illumination.

\section{Polymorphism analysis}

All data concerning the 4 restriction enzymes and their restriction patterns are summarized in Table 1 . Aliquots of $0.1 \mathrm{U}$ of BsmI, FokI and ApaI and $3 \mathrm{U}$ of TaqI restriction enzymes (Fermentas, Lithuania) and $2 \mu \mathrm{L}$ buffer were added to $4 \mu \mathrm{L}$ of the VDR PCR products. The alleles were designated as $B(650 \mathrm{bp}$ and $175 \mathrm{bp}$ fragments) and $b$ (825 bp fragment) for BsmI, F (196 bp and 69 bp fragments) and $f(265 \mathrm{bp}$ ) for FokI 


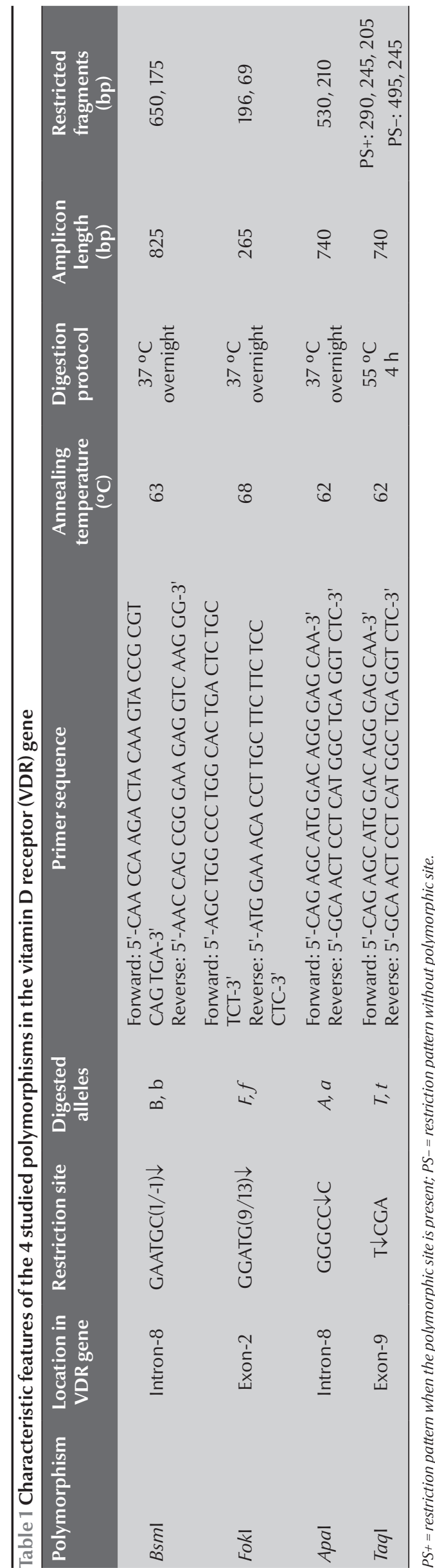

and $A$ (530 bp and $210 \mathrm{bp}$ ) and a (740 bp) for ApaI. TaqI has 2 binding sites on the PCR product, one product a $495 \mathrm{bp}$ and a $245 \mathrm{bp}$ fragment $(t)$ and the other at the single nucleotide polymorphism site in the presence of which the $495 \mathrm{bp}$ fragment will be cut into a smaller $290 \mathrm{bp}$ piece and a $205 \mathrm{bp}$ piece $(T)$.

\section{Statistical analysis}

Data were analysed using SPSS, version 11.5 statistical software. Comparisons of genotype frequencies between groups were performed using the t-test. The chi-squared test was used for analysis of the difference between the 2 groups. $P$-value $<0.05$ was considered significant.

\section{Results}

The patients were 28 males (40.6\%) and 41 females (59.4\%). The mean age of patients was 22.2 (SD 8.7) years and the mean age onset of diabetes was 13.4 (SD 6.1) years. Family history of DM was positive for 26 patients (37.7\%). The frequency of complications of diabetes, including history of ketoacidosis, hypertension, retinopathy, nephropathy and dyslipidaemia, are shown in Table 2. There were 50 patients $(72.5 \%)$ with acute onset of diabetes and 19 patients (27.5\%) with chronic onset. The control group consisted of $19(42.2 \%)$ men and 26 (57.8\%) women with a mean age of 19.7 (SD 6.2) years.

The distributions of VDR gene polymorphism in patients and control groups are shown in Table 3. The genotype frequencies were higher in the patients than the controls for the bb genotype ( $42.6 \%$ versus $40.0 \%, P=0.14$ ) and the $T T$ genotype ( $49.3 \%$ versus $44.4 \%$, $P=0.057)$ although the differences were not significant. However, the frequencies of genotypes were significantly higher in the patient group versus controls for the $A a$ genotype (75.4\% versus $40.0 \%, P=$ $0.003)$, FF genotype ( $55.1 \%$ versus $40.0 \%, P=0.008)$ and $B b$ genotype ( $37.7 \%$ versus $24.4 \%, P=0.014)$.

We stratified type $1 \mathrm{DM}$ patients based on their onset pattern of disease and assessed the relationship to the types of VDR gene polymorphisms (Table 4). The relationship between VDR gene polymorphisms and onset pattern of diabetes was not significant in any of restriction sites. The age of onset of disease did not affect the distribution of genotype frequencies in type $1 \mathrm{DM}$ patients. Moreover, there was no significant difference between the distribution of genotype frequencies (BsmI, ApaI, FokI and TaqI) and chronic complications of diabetes, but the relation between the Ff genotype and history of ketoacidosis was significant $(P=0.04)$.

The electrophoresis pattern of the 4 restriction enzymes is illustrated in Figure 1.

\section{Discussion}

The molecular mechanisms of pathogenesis of type $1 \mathrm{DM}$ remain to be elucidated. Several studies have recently reported an association 


\begin{tabular}{|c|c|c|c|c|}
\hline $\begin{array}{l}\text { Table } 2 \text { Frequencies of complication } \\
(\boldsymbol{n}=69)\end{array}$ & ts wit & pe $1 \mathrm{~d}$ & tes $\mathrm{m}$ & \\
\hline Complication & & ive & & ive \\
\hline & No. & $\%$ & No. & $\%$ \\
\hline History of ketoacidosis & 39 & 56.5 & 30 & 43.5 \\
\hline Hypertension & 2 & 2.9 & 67 & 97.1 \\
\hline Retinopathy & 8 & 11.6 & 61 & 88.4 \\
\hline Nephropathy & 6 & 8.7 & 63 & 91.3 \\
\hline Dyslipidaemia & 14 & 20.3 & 55 & 79.7 \\
\hline Concomitant autoimmune disorders & 6 & 8.7 & 63 & 91.3 \\
\hline
\end{tabular}

between type $1 \mathrm{DM}$ and VDR gene polymorphisms. This study demonstrated a significantly higher frequency of $A a, F F$ and $B b$ genotypes in the VDR receptor in type $1 \mathrm{DM}$ patients in an Iranian population. The frequency of $b b$ and $T T$ genotypes were also higher in patients compared with the control group, but the differences were not statistically significant.

Several populations with different genetic background have been studied for the association of type $1 \mathrm{DM}$ and VDR gene polymorphisms, and contradictory results have been shown. The results of the first published study in

southern India showed that the $b$ allele of BsmI in VDR was more prevalent in type $1 \mathrm{DM}$ patients than healthy controls [18]. Chinese investigators showed in their Han population that the frequency of the $B$ allele of $B s m I$ site gene was significantly higher in type 1 DM [19]. In a Taiwanese population type $1 \mathrm{DM}$ was also associated with the $B$ allele [20]. In Barcelona, Spain, the frequencies of $b b$, and especially combined $b b / F F$ genotypes, were higher in type $1 \mathrm{DM}$ patients than in controls [21]. However, in a Finnish population VDR polymorphisms had no association with type 1 DM [24],

\begin{tabular}{|c|c|c|c|c|c|}
\hline \multirow[t]{2}{*}{ VDR polymorphism } & \multicolumn{2}{|c|}{$\begin{array}{c}\text { Cases } \\
(n=69)\end{array}$} & \multicolumn{2}{|c|}{$\begin{array}{c}\text { Controls } \\
(n=45)\end{array}$} & \multirow[t]{2}{*}{$P$-value } \\
\hline & No. & $\%$ & No. & $\%$ & \\
\hline \multicolumn{6}{|l|}{ BsmI } \\
\hline $\mathrm{bb}$ & 29 & 42.0 & 18 & 40.0 & 0.109 \\
\hline BB & 14 & 20.3 & 16 & 35.6 & 0.715 \\
\hline $\mathrm{Bb}$ & 26 & 37.7 & 11 & 24.4 & 0.014 \\
\hline \multicolumn{6}{|l|}{ Fokl } \\
\hline $\mathrm{ff}$ & 6 & 8.7 & 7 & 15.6 & 0.782 \\
\hline $\mathrm{FF}$ & 38 & 55.1 & 18 & 40.0 & 0.008 \\
\hline $\mathrm{Ff}$ & 25 & 36.2 & 20 & 44.4 & 0.456 \\
\hline \multicolumn{6}{|l|}{ Apal } \\
\hline аа & 4 & 5.8 & 1 & 2.2 & 0.180 \\
\hline $\mathrm{AA}$ & 13 & 18.8 & 18 & 40.0 & 0.369 \\
\hline $\mathrm{Aa}$ & 52 & 75.4 & 26 & 40.0 & 0.003 \\
\hline \multicolumn{6}{|l|}{ TaqI } \\
\hline $\mathrm{tt}$ & 7 & 10.1 & 8 & 17.8 & 0.796 \\
\hline TT & 34 & 49.3 & 20 & 44.4 & 0.057 \\
\hline $\mathrm{Tt}$ & 28 & 40.6 & 17 & 37.8 & 0.101 \\
\hline
\end{tabular}

and a study in Santiago on children with type $1 \mathrm{DM}$ demonstrated that the frequency of the $b$ allele and $b b$ genotype was significantly lower compared with the control group [22]. Surprisingly, a meta-analysis in 2006 also showed that there was no association between VDR gene polymorphisms and type 1 DM risk in case-control and family transmission studies [25].

In our study no significant relationship was found between VDR polymorphisms and the onset pattern of diabetes (acute or chronic). Motohashi et al. in a study of 203 type $1 \mathrm{DM}$ patients compared with healthy controls found that there was a significant difference in the frequency of the $B$ allele in the BsmI site between acute-onset diabetes and control groups. However, the difference between the slow-onset type $1 \mathrm{DM}$ group and controls was not significant and they concluded that assessment of this VDR gene polymorphism may contribute to prediction of the onset pattern in individuals with a high-risk component of type $1 \mathrm{DM}$ [23].

No significant association was found between VDR gene polymorphisms and chronic complications of diabetes (including nephropathy, retinopathy, dyslipidaemia and hypertension). Taverna et al. in Paris observed 200 patients with type $1 \mathrm{DM}$ and found that the Tt genotype was associated with severe retinopathy. In that study, patients with $\pi$ genotype were low risk for severe diabetic retinopathy [26]. We found no association between VDR gene polymorphisms and diabetic retinopathy. It seems that vitamin $\mathrm{D}$ functions may play a role in the pathogenesis of hypertension as a negative endocrine regulator of renin biosynthesis [27] and have a favourable effect on cardiovascular disease $[28,29]$. Other researchers have also reported an association between the $b b$ genotype and severe coronary stenosis [30].

We found a significant relationship between the Ff genotype and a history of ketoacidosis among our patients. To 


\begin{tabular}{|c|c|c|c|c|c|c|c|c|c|c|}
\hline \multirow[t]{2}{*}{ VDR polymorphism } & \multicolumn{2}{|c|}{$\begin{array}{l}\text { With history of } \\
\text { ketoacidosis } \\
\quad(n=39)\end{array}$} & \multicolumn{2}{|c|}{$\begin{array}{l}\text { Without history of } \\
\text { ketoacidosis } \\
(n=30)\end{array}$} & \multirow[t]{2}{*}{$P$-value } & \multicolumn{2}{|c|}{$\begin{array}{l}\text { Acute onset } \\
\quad(n=50)\end{array}$} & \multicolumn{2}{|c|}{$\begin{array}{l}\text { Chronic onset } \\
\qquad(n=19)\end{array}$} & \multirow[t]{2}{*}{$P$-value } \\
\hline & No. & $\%$ & No. & $\%$ & & No. & $\%$ & No. & $\%$ & \\
\hline \multicolumn{11}{|l|}{ Bsml } \\
\hline $\mathrm{bb}$ & 17 & 43.6 & 12 & 40.0 & 0.36 & 31 & 64.0 & 10 & 52.6 & 0.44 \\
\hline BB & 6 & 15.4 & 8 & 26.7 & & 5 & 10.0 & 5 & 26.3 & \\
\hline $\mathrm{Bb}$ & 16 & 41.0 & 10 & 33.3 & & 14 & 26.0 & 4 & 21.1 & \\
\hline \multicolumn{11}{|l|}{ Fokl } \\
\hline $\mathrm{ff}$ & 2 & 5.1 & 5 & 16.7 & & 2 & 4.0 & 2 & 10.6 & \\
\hline $\mathrm{FF}$ & 20 & 51.3 & 18 & 60.0 & 0.04 & 32 & 64.0 & 14 & 73.6 & 0.48 \\
\hline $\mathrm{Ff}$ & 17 & 43.6 & 7 & 23.3 & & 16 & 32.0 & 3 & 15.8 & \\
\hline \multicolumn{11}{|l|}{ Apal } \\
\hline аa & 2 & 5.1 & 2 & 6.7 & & 2 & 4.0 & 0 & 0.0 & \\
\hline AA & 6 & 15.4 & 6 & 20.0 & 0.86 & 4 & 8.0 & 5 & 26.3 & 0.21 \\
\hline $\mathrm{Aa}$ & 31 & 79.5 & 22 & 73.3 & & 44 & 88.0 & 14 & 73.7 & \\
\hline \multicolumn{11}{|l|}{ TaqI } \\
\hline $\mathrm{tt}$ & 2 & 5.1 & 4 & 13.3 & 0.50 & 0 & 0.0 & 1 & 5.3 & 0.27 \\
\hline $\mathrm{TT}$ & 20 & 51.3 & 12 & 40.0 & & 35 & 70.0 & 13 & 68.4 & \\
\hline $\mathrm{Tt}$ & 17 & 43.6 & 14 & 46.7 & & 15 & 30.0 & 5 & 26.3 & \\
\hline
\end{tabular}

our knowledge this is first report of this association. In a study performed on 134 unrelated patients, investigators found that the ff genotype frequency was significantly higher in type $1 \mathrm{DM}$ patients than controls, although the relationship between type $1 \mathrm{DM}$ and chronic complications of diabetes was not analysed [31]. In a Chinese population, the $F$ allele of the FF genotype showed a higher prevalence in patients compared with controls. The FF genotype was suggested as a marker for type $1 \mathrm{DM}$ in this population. However, the authors did not analyse the relation of this genotype with type $1 \mathrm{DM}$ associated complications.

This is the first report comparing the frequencies of all 4 known sites of the VDR gene in healthy and type
1 DM Iranian population. It seems that environmental factors that influence levels of active vitamin D in humans are complex and a significant difference exists between vitamin $\mathrm{D}$ functions and VDR polymorphisms. It further confirms that the association between VDR polymorphisms and type $1 \mathrm{DM}$ varies across different ethnic groups.

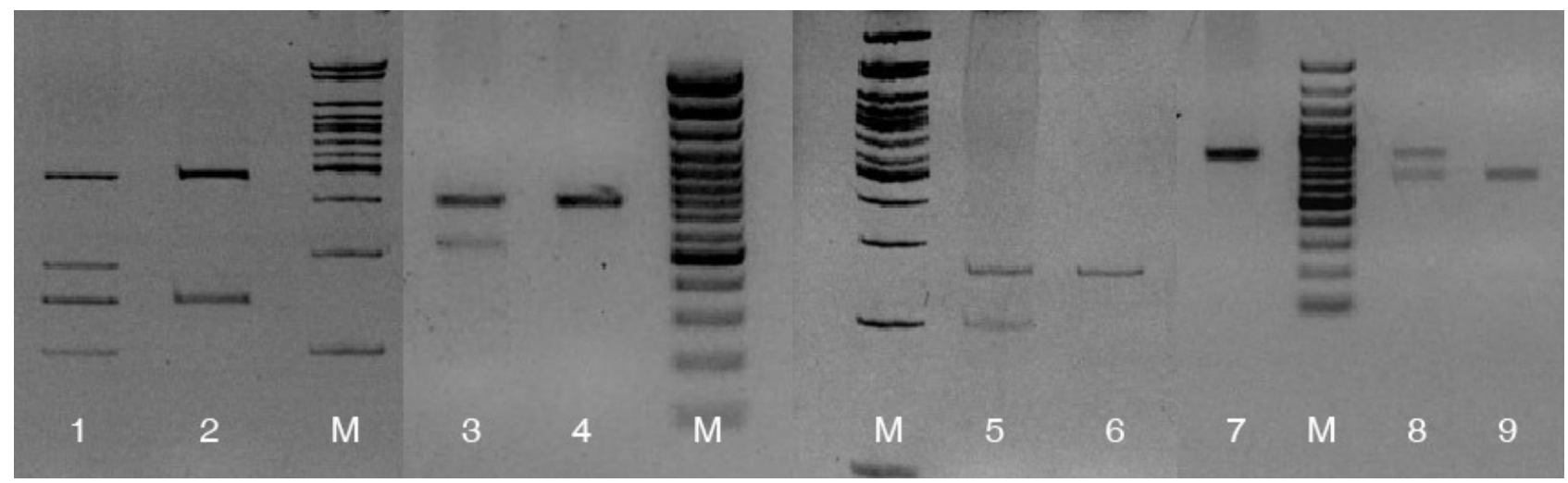

Figure 1 Digestion results of the 4 polymorphism sites. TaqI digestion: $T t$ (lane 1), tt (lane 2); $A p a$ I digestion: $A a$ (lane 3), aa (lane 4); Fokl digestion: $F f$ (lane 5), $f f$ (lane 6); Bsml digestion: $b b$ (lane 7), Bb (lane 8), BB (lane 9). M: 100 bp DNA ladder (Fermentas) 


\section{References}

1. Atkinson MA, Maclaren NK. The pathogenesis of insulindependent diabetes mellitus. New England Journal ofMedicine, 1994, 331:1428-1436.

2. Sunil N, Songqing N, Radharkrishnan R. Noncacemic actions of vitamin D receptor ligand. Endocrine Reviews, 2005, 26:662-687.

3. Provvedini DM, Manolagas SC. 1 alpha 25-dihydoxyvitamin D3 receptor distribution and effects in subpopulations of normal human T lymphocyte. Journal of Clinical Endocrinology and Metabolism, 1989, 68:774-779.

4. Bhalla AK et al. 1,25-dihydroxyvitamin D3 inhibits antigen-induced T cell activation. Journal of Immunology, 1984, 133:17481754.

5. Deluca HF, Cantorna MT. Vitamin D: its role and use in immunology. FASEB Journal, 2001, 15:2579-2585.

6. Adorini L. Immunomodulatory effects of vitamin D receptor ligands in autoimmune disease. International Immunopharmacology, 2002, 2:1017-1028.

7. Hypponen $\mathrm{E}$ et al. Intake of vitamin $\mathrm{D}$ and risk of type 1 diabetes: a birth- cohort study. Lancet, 2001, 358:1500-1503.

8. Gyorffy B et al. Gender-specific association of vitamin D receptor polymorphism combinations with type 1 diabetes mellitus. European Journal of Endocrinology, 2002, 147:803808.

9. Vitamin D supplement in early childhood and risk for type I (insulin-dependent) diabetes mellitus. The EURODIAB Substudy 2 Study Group. Diabetologia, 1999, 42:51-54.

10. Mathieu C, Adorini L. The coming of age of 1,25-dihydroxyvitamin D3 analogs as immunomodulatory agents. Trends in Molecular Medicine, 2002, 8:174-179.

11. Morgan JW et al. Vitamin D mediated gene regulation in phenotypically defined B cell subpopulation. Endocrinology, 2000, 141:3225-3234.

12. Veldman CM, Cantorna MT, DeLuca HF. Expression of 1,25 dihydroxyvitamin D3 receptor in the immune system. Archives of Biochemistry and Biophysics, 2000, 374:334-338.

13. Brennan A et al. Dendritic cells from human tissues express receptors for the immunomodulatory vitamin D3 metabolite, dihyroxycholecalciferol. Immunology, 1987, 61:457-461.

14. Uitterlinden $A$ et al. Genetic and biology of vitamin $D$ receptor polymorphisms. Gene, 2004, 338:143-156.

15. Hitman GA et al. Vitamin D receptor gene polymorphisms influence insulin secretion in Bangladeshi Asian. Diabetes, 1998 47:688-690.

16. Yaylım-Eraltan I et al. Investigation of the VDR gene polymorphisms association with susceptibility to colorectal cancer. Cell Biochemistry and Function, 2007, 25(6):731-737.
17. Pani MA et al. Vitamin D receptor allele combinations influence genetic susceptibility to type 1 diabetes in Germans. Diabetes, 2000, 49:504-507.

18. Mcdermott MF et al. Allelic variation in the vitamin D receptor influence susceptibility to IDDM in Indian Asian. Diabetologia, 1997, 40:971-975.

19. Xiao XH et al. Effects of vitamin D receptor gene polymorphisms on susceptibility to type 1 diabetes mellitus. Chinese Medical Sciences Journal, 2006, 21:95-98.

20. Chang TJ et al. Vitamin D receptor gene polymorphisms influence susceptibility to type 1 diabetes mellitus in the Taiwanese population. Clinical Endocrinology, 2000, 52:575-580.

21. Marti G et al. Association of vitamin D receptor gene polymorphism with type 1 diabetes mellitus in two Spanish populations. Medicina Clínica, 2004, 123:286-289.

22. Garcia D et al. VDR polymorphisms influence the immune response in type 1 diabetic children from Santiago, Chile. Diabetes Research and Clinical Practice, 2007, 77:134-140.

23. Motohashi $\mathrm{Y}$ et al. Vitamin $\mathrm{D}$ receptor gene polymorphism affects onset pattern of type 1 diabetes. Journal of Clinical Endocrinology and Metabolism, 2003, 88:3137-3140.

24. Turpeinen $\mathrm{H}$ et al. Vitamin $\mathrm{D}$ receptor polymorphisms: no association with type 1 diabetes in the Finnish population. European Journal of Endocrinology, 2003, 149:591-596.

25. Guo SW et al. Meta-analysis of vitamin D receptor polymorphisms and type 1 diabetes: a huge review of genetic association studies. American Journal of Epidemiology, 2006, 164:711-724.

26. Taverna MJ et al. Taql polymorphism of the vitamin D receptor and risk of sever diabetic retinopathy. Diabetologia, 2002, 45:436-442.

27. Qiao G et al. Analogs of alpha, 25-dihydroxyvitamin D3 as novel inhibitors of rennin biosynthesis. Journal of Steroid Biochemistry and Molecular Biology, 2005, 96:59-66.

28. Shoji T et al. Lower risk for cardiovascular mortality in oral $1 \mathrm{al}$ pha hydroxyl vitamin D3 users in a haemodialysis population. Nephrology, Dialysis, Transplantation, 2004, 19:179-184.

29. Park CW et al. Intravenous calcitriol regresses myocardial hypertrophy in hemodialysis patients with secondary hyperparathyroidism. American Journal of Kidney Diseases, 1999, 33:73-81.

30. Van Schooten FJ et al. Putative susceptibility markers of coronary artery disease: association between genotype, smoking and aromatic DNA adduct level in human right atrial tissue. FASEB Journal, 1998, 12:1409-1417.

31. Zemunik T et al. Fok I polymorphism, vitamin D receptor, and interleukin-1 receptor haplotypes are associated with type 1 diabetes in the Dalmatian population. Journal of Molecular Diagnostics, 2005, 7:600-604. 